\title{
Autorita ve virtuálním vzdělávání
}

\author{
Marie Dlouhá
}

Envigogika 2011/VI/2- Recenzované články/ Reviewed Papers

Publikováno/Published 30. 09. 2011

DOI: http://dx.doi.org/10.14712/18023061.60

\begin{abstract}
Abstrakt:
ITC technologie začínají v posledních desetiletích pronikat do různých oblastí společenského života, jednou z takovýchto oblastí je např́klad právě vzdělávání. Nové formy vyučování nazývané e-learning či virtuální vzdělávání poukazují mj. na specificitu vztahu učitele a žáka. Text Autorita ve virtuálním vzdělávání se snaží odkrýt charakteristiky tohoto vztahu, který je podmíněn komunikací, jež se nemusí odehrávat v kontaktu tváŕí v tvář. Autorka vychází z teoretického rozboru (založeného především na relevantních dílech $\mathrm{M}$. Webera a J. S. Colemana), na jehož základě realizovala případovou studii e-learningového kurzu Multiple Perspectives on Globalisation and Sustainable Development, který byl organizován Centrem pro otázky životního prostředí UK. $\mathrm{V}$ rámci tohoto kurzu je pak provedena obsahová analýza textů, které byly publikovány jak učiteli, tak studenty $v$ elektronickém prostředí Moodle, zkoumány jsou i funkce tohoto prostředí. Tato analýza odhaluje, kdo jsou hlavní aktéři virtuálního vztahu, a ukazuje tak jeho vnitřní, skrytou strukturu - za účastníky je kromě nositele autority (učitele), př́ijemce autority (studenta) považováno i samotné elektronické prostředí. Př́itomnost prostředí umožňuje, dle autorky, učiteli vystupovat v "akční" části kurzu ve vztahu ke studentovi jako partner a v kurzu jako celku neřídit jeho jednání omezujícím zpưsobem. Takovéto projevy autority jsou chápány jako možné právě díky využívání elektronického softwaru, který tyto funkce zastupuje. Prostřednictvím něho jsou vytyčovány jisté mantinely, ve kterých se může odehrávat jednání studentů, vytváření hranic je tak zdánlivě nezávislé na učitelích.
\end{abstract}

\section{Klíčová slova:}

E-learning, virtuální vzdělávání, autorita, J. S. Coleman, př́padová studie, obsahová analýza

\section{Abstract:}

In the past few decades ITC technologies have begun to penetrate various areas of social life. One of these areas is education. New forms of teaching and learning have appeared - for example, e-learning or virtual learning; this term refers to the specificity of the relationship between teacher and student. The work Authority in virtual education tries to uncover the characteristics of this relationship, which are substantially influenced by communication that excludes face-to-face contact. The author draws on a theoretical analysis (based primarily on the relevant works of Max Weber and JS Coleman), and on this basis she compiled the case study of the e-learning course Multiple Perspectives on Globalisation and Sustainable Development, which was organized by the Charles University Environment Centre. A content analysis was undertaken of the texts that were part of this course and which were published by both teachers and students in the Moodle electronic environment; the functions of this environment were also investigated. This analysis revealed who are the major players in the virtual relationship and thus shows the hidden 
structure of this relationship - parties in this relationship are considered to be not only the holder of authority (the teacher), the recipient of the authority (student), but also the electronic environment. According to the author, the virtual environment allowed the teacher to function as a partner in relation to the student in the "action" part of the course, and not manage his or her activities in a restrictive way in the course as a whole. Such manifestations of authority are seen as possible thanks to the use of electronic software, which these functions substitute. The environment sets some constraints in which the actions of students can take place; the creation of borders is thus seemingly independent of teachers. To verify the results, the feedback provided by one of the actors is used.

\section{Key words:}

E-learning, virtual learning, authority, J. S. Coleman, case study, content analysis

\section{Úvod}

Technologický pokrok minulého století $s$ sebou přinesl i změny $v$ oblasti každodenního života, stal se součástí běžných aktivit a jeho neodmyslitelné místo je také v oblasti interpersonální komunikace a vzdělávání. Z hlediska sociální interakce nacházíme změny v komunikaci, zpưsobech setkávání či předávání informací. Typickými znaky, které s sebou technologický vývoj přinesl, je možnost transferu velkého objemu informací. Můžeme zaznamenat též irelevanci prostoru $v$ komunikaci - ten je překonáván prostřednictvím informačních a komunikačních technologií (ICT), propojujících $v$ reálném čase místa libovolně vzdálená, a využívajících velké rychlosti, kterými mohou být data a informace přenášeny (Cartelli, 2006: 55).

Zaměříme-li se konkrétně na oblast vzdělávání a důsledky, které zde způsobuje přítomnost ITC technologií, nesmíme opomenout nově se objevující výukové situace, které již nutně nevyžadují přímou komunikaci mezi učitelem a studentem tváří v tvář. Taková situace nastává, např́klad pokud se výuka přenese plně anebo částečně do virtuálního prostředí (e-learning nebo blended learning), a vede k novým formám vzájemného vyjednávání rolí a postavení jednotlivých aktérů. Ve výzkumu, jemuž se budu věnovat níže, jsem se zaměřila především na podobu autority, která se objevuje právě v e-learningovém prostředí.

\section{Výzkum}

Na téma autority ve virtuálním vzdělávání byla provedena kvalitativní studie, podnětem pro tento výzkum byl především fakt, že přestože e-learning je fenoménem poměrně aktuálním, výzkumů na toto téma nebylo provedeno příliš mnoho. Úvodní práci s teoretickými zdroji jsem si rozdělila na dvě oblasti - na jedné straně jsem zkoumala autoritu jako takovou, na druhé straně autoritu ve vzdělávání, s konkrétním zaměřením na texty věnující se virtuálnímu prostředí. Mezi nejznámější autory obecného pojetí autority, které následně využiji i ve své práci, patří dílo Maxe Webera (Weber, 1997), na které na základě společných rysů v pojetí autority navazuji (především v oblasti metodologie) prací J. S. Colemana (1994). Co se týče problému autority v rámci vzdělávání, je v literatuře tento koncept často spojován s evaluačním přístupem - autorita je chápána jako fenomén, který mưže a nemusí být $v$ rámci vzdělávání přítomný, jeho přítomnost totiž bývá spojována s představami nesvobody a nesamostatnosti, je na něj nahlíženo jako na něco, čeho je třeba se zbavit pro efektivní průběh vzdělávání (Waller, 1961: 383). V opozici proti tomuto negativnímu př́stupu stojí např́klad Durkheim (1922: 19), který vyzdvihuje význam autority a její socializační složky; v jeho pojetí není autorita omezujícím prvkem, ale prvkem zmocňujícím. Ve své práci však využiji spíše obecné přístupy Webera a Colemana, kteří přistupují $k$ autoritě jako $k$ něčemu, co je nedílnou součástí společenských vztahů. Mezi další teoretiky autority $v$ klasickém vzdělávání jmenujme 
např́klad dílo Peaceho (2003, 2007) Steutela a Spieckera (2000) a Tirriové a Puolimatky (2000), kteří stejně jako Durkheim mluví o socializační funkci autority a navíc zdůrazňují roli, kterou hraje ve vztahu učitel-žák prostředí (což je inspirací pro zkoumání role e-learningového prostředí v případě mého výzkumu). Zmiňme i práce, které berou $v$ potaz neverbální složku komunikace, s jejíž nepřítomností (či změněnou podobou) se $v$ rámci virtuálního prostředí setkáváme (Babad, 2009: 817). Mezi ne přiliš četné studie věnující se konkrétně vztahům autority $v$ e-learningu můžeme jmenovat např́klad článek Where is the teacher (Linser et al., 2004), jde však o dílo cizojazyčné; v českém prostředí výzkumy tohoto druhu prakticky chybí. Hlavním zjištěním práce těchto tří autorů, které jsem využila v rámci svého výzkumu, je sledování změny role učitele, která nastala právě díky specificitě virtuálního prostředí, ve kterém se vyučování odehrává. Mým cílem bylo tedy nejen ukázat možné trendy vývoje $v$ této oblasti, ale i navrhnout nástroj či základ pro další zkoumání této problematiky.

Jak již bylo řečeno, jde o oblast poměrně málo zmapovanou, proto jsem se zaměřila na zachycení základních charakteristik týkajících se problému autority; zvolila jsem př́padovou studii jednoho e-learningového kurzu Centra pro otázky životního prostředí (COŽP) Univerzity Karlovy Multiple Perspectives on Globalisation and Sustainable Development (MPG\&SD) ${ }^{1}$, který probíhal v zimním semestru roku 2009/2010 a byl určen studentům bakalářského i magisterského studia různých oborů. Šlo o volitelný kurz, který byl ohodnocen 5 evropskými kredity a který byl otevřen studentům z dalších evropských univerzit. Kurz byl součástí projektu VCSE - "Virtual Campus for a Sustainable Europe"2 a účastnilo se jej 12 studentů a 3 učitelé z pražské Univerzity Karlovy a německé University of Lüeneburg. Jako hlavní jazyk kurzu byla zvolena angličtina, která je komunikačním jazykem v síti VCSE.

Celý kurz probíhal virtuální formou - byl strukturován prostřednictvím internetového softwaru Moodle (jedná se o software přímo určený $k$ výuce $v$ on-line prostředí), komunikace probíhala $v$ internetových fórech (dostupných $v$ Moodlu) a pomocí e-mailu, chatu apod. Součástí kurzu bylo i wiki ${ }^{3}$ prostředí, které je založené na stejném principu jako klasická Wikipedie ${ }^{4}$, kde se odehrávala samostatná práce studentů. Kontakt tváří v tvář mezi učiteli a studenty pro absolvování kurzu nebyl podmínkou (a reálně nenastal), což z hlediska výuky představovalo zcela specifickou výukovou situaci a z výzkumného hlediska umožňovalo zkoumat podobu autority ve virtuálním vztahu učitele a studenta.

\section{Teoretická východiska}

Cílem mé práce bylo zkoumat základní podmínky a předpoklady výuky $v$ tomto konkrétním prostředí - tedy především zjistit, jakým způsobem se utváří vztah učitele a žáka, jakou roli hraje autorita a kdo (či zda vưbec někdo) je jejím nositelem; nekladla jsem si tedy za cíl získat výsledky, které by bylo možné zobecnit na e-learning obecně, což ani při malém počtu studentů $v$ kurzu nebylo možné. Jako metodu jsem proto zvolila

\footnotetext{
1 Základní informace o e-learningových kurzech COŽP UK jsou dostupné na oficiálních stránkách COŽP-Environmentální vzdělávání: http://cozp.cuni.cz/COZP-247.html

2 Webová stránka VCSE: http://www.vcse.eu/

3 Wiki prostředí využívané $v$ kurzu je veřejně přistupné a je dostupné na: http://www.czp.cuni. $\mathrm{cz} / \mathrm{vcsewiki/index.php/Student} \mathrm{Area}$

${ }^{4}$ Wiki patři mezi Web 2.0 nástroje, o kterých se hovoří jako o "sociálním webu"; jde o soubor vzájemně propojených webových stránek, které mưže jednoduše editovat kdokoli. Umožňuje kolektivní práci na textu, jeho úpravy i diskusi týkající se obsahu, a také srovnávání různých variant a případné návraty $\mathrm{k}$ "historicky starším" verzím textu (to je důležité vzhledem k veřejné povaze wiki prostoru a související hrozbě vandalizmu). Po technické stránce poskytuje tento software nesčetné možností pro tvorbu textů, vkládání obrázků a grafů, propojování s dalšími zdroji četnými hyperlinky atd.
} 
obsahovou analýzu ${ }^{5}$ textů psaných studenty a pedagogy, zveřejněných a archivovaných v rámci kurzu MPG\&SD, na jejichž analýze jsem pak založila svoji kvalitativní prípadovou studii. $V$ rámci zkoumání jsem věnovala prostor i analýze role samotného technického prostředí. Virtualita kontaktu mezi zkoumanými aktéry umožňovala výhradně psanou komunikaci, což bylo důvodem pro volbu textové analýzy.

Do souboru analyzovaných textů byly zařazeny pouze původní texty, které byly vytvořeny a publikovány bud' pedagogy nebo studenty $v$ rámci e-learningového kurzu především $\vee$ internetových fórech - představujících prostředí pro řízenou komunikaci $\checkmark$ rámci systému Moodle.

Texty, které se takto staly předmětem mé analytické činnosti, byly rozděleny do čtyř skupin, které jsem označila jako vstup do prostředí (týkaly se základních informací o kurzu, virtuální komunikace a zacházení s elektronickým prostředím), ohraničení výukových modulů, do kterých byl kurz rozčleněn (jednalo se především o texty zabývající se zadáváním a hodnocením úkolů $v$ jednotlivých částech), pohyb $v$ prostředí (šlo o konkrétní plnění úkolů, diskuse mezi učiteli a studenty) a výstup (celkové hodnocení ze strany učitelů i studentů). Toto rozčlenění mi umožňovalo sledovat, $v$ jaké míře a jakým způsobem se utváŕí autorita učitele $v$ jednotlivých fázích vyučovacího procesu a komunikačního aktu.

Vycházejíc $z$ práce $s$ literaturou jsem si $v$ úvodu definovala základní pojmy a na tomto základě pak bylo možné dále zvolit konkrétní nástroj, jakým budou texty analyzovány. Autoritu jako takovou jsem se snažila uchopit $z$ obecné perspektivy, především na základě děl Maxe Webera ${ }^{6}$ a J. S. Colemana ${ }^{7}$ (důvody a konkrétní využití Colemanova př́istupu uvedu níže $v$ oddíle zabývajícím se metodologií výzkumu). Základním teoretickým východiskem bylo pojetí autority u Maxe Webera, který ji chápe jako nedílnou součást společnosti - je složena ze vztahů ovládaných a ovládajících, mocenský prvek je tedy neustále př́tomný (Weber, 1997: 47). Definuje ji ve vztahu k moci, která oproti autoritě není podmíněna legitimitou (ibid.: 47-50). Z jeho konceptu využiji pro svoji práci pojetí autority jako něčeho, co brání chaosu a umožňuje lidem dosáhnout určitého cíle. Právě Weberův př́stup jsem zvolila proto, že Coleman na něj ve svém díle na několika místech navazuje (podobnost vidíme $v$ oné racionalitě při dosahování určitých cílů). $\checkmark$ jistém smyslu se však pojetí J. S. Colemana od koncepce Maxe Webera liší. Touto jinakostí, kterou využiji pro zkoumání e-learningového kurzu, je především jejich rozdílný pohled na autoritu jako strukturu (Weber) či jako na vztah ${ }^{8}$ (Coleman - tomu, jak Coleman autoritu konkrétně chápe, se budu věnovat dále), který se právě stal inspirací k sestavení metodologického nástroje. $Z$ hlediska pochopení autority př́mo ve vzdělávání jsem se zabývala problémem, zda je autorita ve vzdělávání potřebná a stále př́tomná, jaký je na ni kladen důraz $v$ opozici ke svobodě (viz například (Pace, 2003), (Waller, 1961) a (Durkheim, 1922)) a jakou roli hraje v procesu výuky ve specifickém prostredí, kde se proces učení odehrává (Tirri, Puolimatka, 2000: 159).

\footnotetext{
${ }^{5}$ Je nutné poznamenat, že se jedná o obsahovou analýzu kvalitativního charakteru. Přestože tedy pracuji s jistou mírou kvantifikace - na data využívám kódovacího schématu, sleduji četnosti jednotlivých kódů - tato kvantifikace pro mne není primární, slouží především $v$ orientaci $v$ datech, zjištóvání toho, na co je kladen důraz. Hlavním stěžejním bodem analýzy je však interpretace.

${ }^{6}$ WEBER, M.: Autorita, etika a společnost. Praha: Mladá Fronta, 1997.

7 COLEMAN, J.: Foundations of social theory. Cambridge: Belknap Press of Harvard University Press, 1994.

8 Dle Colemana není Weber schopen zachytit, jakým způsobem vzniká stabilita systému - souvztažnost pozic nezávislých na lidech (přechod z mikroroviny do makroroviny) (Coleman, 1994: 169-171).
} 
V samotné analýze jsem se opírala o Durkheimův názor, že autorita je nezbytnou součástí výukového procesu a že nestojí $v$ protikladu ke svobodě. Jak sám říká, být svobodný neznamená činit, co chceme, znamená to být svým pánem, jednat rozumně a plnit své úkoly, což je umožněno právě díky vnější autoritě, v závislosti na níž si jedinec osvojuje morální a společenská pravidla (Durkheim, 1922: 21).

Autoritu pak definuji na základě prací Colemana jako "právo na možnost ovlivňovat a kontrolovat jednání druhého" (Coleman, 1994: 66). Mohli bychom tedy říci, že v určité doméně je nositelem autority ten aktér, který může (či má právo) ř́́dit jednání někoho jiného). Ten pak ovlivňuje jednání druhého tak, že ten druhý vykoná něco, co by sám od sebe nevykonal. Takový př́stup se soustřed'uje na interakci mezi jednotlivci, což znamená, že i ve své studii jsem si zvolila sledování vyjednávání autority $v$ jednoduchých vztazích (např. učitel - žák) a ne ve více komplexních formách těchto vztahů (jako např. škola - studenti).

Na Colemana jsem navázala nejen tím, že jsem použila jeho definici autority, a tuto autoritu jsem na tomto základě následně zkoumala, ale i využitím jeho dalšího rozpracování a klasifikace tohoto fenoménu. Jeho racionalistické chápání autority v podstatě pojímá tento vztah, do kterého vstupují aktéři s rưznými zdroji (at́ již materiálními či nemateriálními), jako vzájemnou směnu, ze které mají určitý prospěch všichni aktéři - s jedněmi zdroji vstupují a jiné získávají (Coleman, 1994: 66). Důvodem, proč využívám Colemanovu koncepci vztahủ autority, jsou především odlišnosti virtuálního prostředí od prostředí klasického. Na rozdíl od běžného prostředí není během výuky, předávání informací a zkušeností a výměny názorů v dialogu většinou př́tomno více osob, nejedná se tedy o "masu" lidí. V e-learningu jde zejména o kontakt "jednoho s jedním" - i u příspěvků, které jsou adresovány všem, se musí již při jejich tvorbě brát v potaz to, že budou čteny individuálně. Druhým důvodem využití Colemanova př́stupu je i to, že jeho pojetí je racionalistické - chápe vztah autority jako směnu. Adekvátnost tohoto pojetí vidím především $v$ tom, že ve zkoumaném případě se jedná o kurz dobrovolný - studenti mohou být pojímáni jako aktéři, kteří předem zvážili benefity, které jim participace $v$ kurzu může přinést, a na základě toho se rozhodli stát se účastníky. I ze strany učitelư může být podíl na tomto druhu autoritativního vztahu chápán jako směna - mohou zde dosáhnout určitého platového ohodnocení, uznání (společenský benefit), seberealizace, dobrého pocitu, že přispívají k vzdělání studentů apod. Toto pojetí korespondovalo $s$ účelem, pro nějž jsem jeho klasifikaci využila - ke konstrukci analytického kódovacího schématu, který mi umožnil určit, jaké kategorie budu následně vyhledávat v textu.

Autorita tj. konkrétní př́pad, kdy (byt' i nevědomky) objekt autority deleguje právo na řízení svého jednání ( $v$ tomto př́padě je podřízeným student), je $v$ textu Authority relations vymezena čtyřmi základními parametry (Coleman, 1994: 82-86). Coleman nepřistupuje $k$ přesné definici, jednotlivé typy ilustruje na konkrétních případech - a na tomto základě se je pokusím vymezit i já. V první řadě Ize dle Colemana autoritu ohraničit rozsahem aktivit, tj. také obsahem aktivit, které jsou delegovány na druhou osobu ( $v$ mém schématu jsem tuto kategorii nazvala vymezení obsahu) - v Colemanových př́kladech se jedná třeba o množství práce a jejího obsahu; dále časovým obdobím, ve kterém má druhý právo řídit jednání aktéra (vymezení času) - jedná se především o časové vymezení začátku a konce, kdy je nositel autority oprávněn ovlivňovat jednání podř́zeného; Ize ji ohraničit i z hlediska prostoru, kde je dovoleno projevovat autoritu (vymezení prostoru) - tj. především konkrétní lokace v prostoru, kde je autorita vykonávána; a nakonec též mírou a způsobem, jakým se tak děje - jde především o to, zda je prosazována formou př́kazů, co má podř́zený aktér dělat, či formou zákazů, do kterých oblastí by jeho jednání zasahovat nemělo. $V$ tomto prípadě se jedná o míru preskripce či proskripce (preskriptivní normy - předepisují, co se má dělat, proskriptivní - předepisují, co se nemá dělat; rozdíl mezi nimi je v sankcích). K prvním třem kategoriím jsem hledala jak pozitivní formu (kam autorita smí zasahovat), tak i formu negativní (kam zasahovat nesmí). Vzhledem $\mathrm{k}$ tomu, že se diskusní př́spěvky ve fórech silně lišily mírou své direktivity, rozlišovala jsem v poslední kategorii (proskriptivita či preskriptivita jednání) na jedné straně neosobní a direktivní př́kazy, a na druhé straně výzvy motivující, mající formu doporučení. Tyto kategorie, stejně jako negativní a pozitivní formy kategorií 
předchozích, byly generovány přímo z dat (na rozdíl od celkového kódovacího schématu, které bylo vytvořeno a priori především na základě teoretické práce s literaturou).

\section{Data a metody}

Vzhledem k tomu, že jsem se na problematiku snažila dívat z kvalitativního hlediska, sloužilo mi kódovací schéma9 ${ }^{9}$ spíše pro orientaci $v$ datech, získané počty kódů byly spíše orientační, důležitý byl především věcný obsah a způsob komunikace. Jak již bylo řečeno, relevantními zdroji dat se mi staly texty, které byly vytvořeny ve vzájemné komunikaci učitele se studenty, jednalo se o dokumenty původní, pro analýzu byly rozděleny do celků vstup do prostředí, ohraničení vyučovacího modulu, pohyb v prostredí a hodnocení. Při volbě dat pro analýzu k jednotlivým částem jsem většinou použila všechny dokumenty, které se týkaly vymezené oblasti. Tam, kde byl základní materiál početnější, jsem po úvaze zvolila tu část, která je, dle mého názoru, typická pro danou sekci a dostatečně ji reprezentuje. Celkově tedy analyzovaná data tvořilo 49 textů, jejichž délka a charakter byl rozdílný. Výše zmíněné kódovací schéma, založené na teoretickém základě J. S. Colemana, jsem použila v kódování v programu ATLAS.ti, který slouží ke zpracování kvalitativních dat.

Celou analýzu jsem soustředila na tři základní "aktéry"10 - učitele, studenty a elektronické prostředí - kteří hráli roli při utváření relací autority. Primární zde byl vztah učitele se studentem, roli však hrají i podmínky, v jakých se tento vztah utváří - virtuální prostředí kurzu Moodle, které je využíváno pro realizaci vztahu autority samotnými učiteli, což je důvodem, proč jsem ho do analýzy také zařadila jako aktéra.

Na takto zvolená data bylo aplikováno výše zmiňované teoreticky ukotvené kódovací schéma. Jednotlivé počty kódů (týkajících se obsahu, času a prostoru, kam autorita (ne)smí zasahovat a toho, jakým způsobem je vykonávána), které se v korpusu textů vyskytovaly, nejsou pro výzkum primárně určující (i z hlediska toho, že rozsah jednotlivých analyzovaných oddílů má jinou délku), mají spíše orientační charakter. Využitelný pro následnou interpretaci byl zejména obsah jednotlivých okódovaných úseků, počty kódů sloužily pouze k rozpoznávání, na co je kladen v rámci výkonu autority větší či menší důraz. Podrobnosti viz (Dlouhá, 2010).

\section{Zjištění a interpretace}

V jednotlivých analytických částech (vstup do prostředí, ohraničení vyučovacího modulu, pohyb v prostředí a hodnocení) mělo vyjednávání autority, tak jak jsem je zkoumala, trochu jinou podobu, považuji tedy za vhodné shrnout základní zjištění dle jednotlivých oblastí zvlášt'.

Ve vstupní části kurzu byla autorita utvářena především ze strany učitelů, žáci se príliš neprojevovali (nepotvrzovali, ani nevyvraceli ustanovování hranic a pravidel komunikace). Zásahy učitelů směřovaly především do oblastí prostoru - učitelé

\footnotetext{
${ }^{9}$ Kódovací schéma slouží výzkumníkovi ke kódování, které mu "pomáhá popsat data. Kód je symbol přiřazený k úseku dat tak, že ho klasifikuje nebo kategorizuje. Kódy mají mít relevanci k výzkumným otázkám, konceptům nebo tématům" (Hendl, 2008: 228). Pomocí kódovacího schématu se tak výzkumník nejen lépe orientuje $v$ datech, ale také $\mathrm{s}$ jeho pomocí nachází relevantní partie textu, které pak podrobuje následné interpretaci.

${ }_{10} \mathrm{~V}$ uvozovkách z toho důvodu, že budu mluvit též o elektronickém prostředí Moodle, které není prvkem živým, jde o technický nástroj. V tomto smyslu bychom ho mohli chápat spíše jako aktanta $\checkmark$ rámci teorie ANT (Actor Network Theory). Ta nečiní rozdíl mezi vědou (vzděláním) a technologií (výtvory). Předpokládá, že všechny prvky - aktanti, at' již znalosti, prvky, entity a organizace, jsou ve vzájemném vztahu (jenž nezahrnuje pouze lidi), a v těchto vztazích vytváŕí sítě. $v$ tomto smyslu je Moodle aktantem (Harrington et al., 2006: 5-6).
} 
stanovovali, kde přesně se bude jednání odehrávat (hranice virtuálního prostředí), seznamovali studenty $\mathrm{s}$ vnitřními pravidly atd. Jejich jednání mělo spíše preskriptivní charakter, což znamená, že studenti byli řízeni spíše zákazy, bylo určováno, jaké jednání je pro ně nevhodné. Příkladem může být následující úryvek publikovaný jedním z lektorů:

„Když lidé pracují na internetu, obvykle se oslovují křestními jmény. Takže my vás budeme takto oslovovat a vy to samé můžete činit vzhledem k tutorům. Kdyby někdo chtěl být oslovován př́jmením, je to v pořádku, jen to, prosím dejte vědět ostatním!"11

Můžeme zde vidět jak preskriptivitu příspěvku (učitelé nenabízi možnosti např. oslovování, určují, jak to bude, a tím projevují svoji autoritu), tak ale i to, že se príkazy týkají spíše technických, formálních problémů (oficiální oslovování). Konkrétní jednání se studenty (tedy $v$ těch př́padech, kdy se nejedná o technické či organizační problémy) je pak tím, které má proskriptivní charakter, učitelé vystupují více v partnerském vztahu, určité jednání pouze doporučují.

Celkově ve vstupním prostředí můžeme označit roli virtuálního systému jako nepř́liš velkou, zatím se s jeho činností studenti spíše jen seznamovali.

V analytické části, která ohraničovala výukové lekce, měli již studenti k dispozici základní pravidla pohybu a fungování v kurzu. Jednalo se o texty, které studenty uváděly do výukových lekcí, seznamovaly je s dílčími úkoly a posléze je směrovaly k tomu, aby tento prostor opustili a přesunuli se do jiného (další výukové lekce). Největší roli zde hrála opět postava učitele, který poskytoval "vstupní klíče" do jednotlivých sekcí, student se spíše nechával vést. Nejmarkantnější zásahy ze strany vyučujících byly v oblasti obsahu - určovaly, čeho se výuková lekce bude týkat, případně vytyčovaly pravidla hodnocení dle kvality splněných úkolů, př́kladem je následující citace (opět od jednoho z učitelů):

„V této lekci dostanete příležitost vyjádřit svá očekávání, představit se, získat základní orientaci v kurzu, v našem zpưsobu výuky, a seznámíte se s e-learningovým prostředím. Součástí je Etický kodex jednání."12

Zajímavé je, že $v$ této části na rozdíl od části předchozí převažovala pozitivní (příkazová) forma projevů autority. Prvotní základní pravidla byla již určena, úkoly jednotlivých lekcí pak byly prezentovány spíše jako dobrovolná aktivita samotných studentů, jejich činnost byla vedena motivačním zpưsobem. Tento ne př́liš přísný zpưsob byl ale ovlivněn prítomností virtuálního prostředí, které "dohlíželo" na udržování vytyčených mantinelů a otevíralo tak prostor pro partnerský vztah učitele s žákem.

Tento způsob projevu autority, který při pohledu zvenku působí spíše jako partnerství než jako autoritativní řízení, byl markantní především $v$ části pohyb v prostředí, která obsahovala hlavně úseky, kdy spolu přímo interagují učitelé a žáci prostřednictvím diskusí. Zde byla ze strany učitelů ponechána určitá volnost - jemnými pobídkami proskriptivního charakteru spíše směřovali jednání studentů, než aby ho přímo vedli. Snahy o kritické řízení, snahy o omezení překračování hranic i pobídky k práci jsou zde prezentované spíš jako prosby či činnosti dobrovolné:

„Ahoj studenti, ještě jednou, děkuji za všechny vaše zaujaté příspěvky, je potěšení mít takto dobře informované studenty $v$ tomto kurzu! Jen bych chtěla něco dodat ke

$11 \mathrm{~V}$ anglickém originále dostupné na: COŽP. VCSE/Globalisation09/Wikis/Communication tools and rules. In: MPG\&SD, Electronic course in Moodle. (online). (cit. 08-04-2010) Dostupný z internetu pro registrované účastníky: WWW: http://www.vcse.eu/moodle/course/view.php?id=7

$12 \mathrm{~V}$ anglickém originále dostupné na: COŽP. VCSE/Globalisation09.In: MPG\&SD, Electronic course in Moodle. (online). (cit. 08-04-2010) Dostupný z internetu pro registrované účastníky: WWW: http://www.vcse.eu/moodle/course/view.php?id=7 
struktuře naší diskuse a připojit nějaké další pohledy k našemu následnému dialogu a spolupráci..."13

Tento výzkum pak sledoval nejen to, jak probíhá autoritativní řízení, ale i to, jak je přijímáno z druhé strany - studenty (Coleman také pojímá vztah autority jako určitou výměnu mezi dvěma stranami, sledování obou aktérských stran bylo již vstupním principem výzkumu). K zjištěním pak patří, že i ze strany studentů má podřizování se preskriptivnímu řízení autority charakter spíše osobnějšího rázu. Příkazy přijímají a nechají se jimi řídit, dokonce řízení učitelư oceňují, uznávají doporučená témata jako přínosná či obohacující.

To vše bylo ale právě umožněno př́tomností Moodlu, který vykonával skrytou „přísnou složku" a téměř neviditelně "hlídal" jednání studentů - kontroloval včasné odevzdávání úkolů, frekvenci a kvalitu diskusních příspěvků apod. Učitelé tedy díky němu mohli řízení kurzu ze své strany omezit, převést na něj část své autority.

Posledním úsekem, který jsem analyzovala, byla část nazvaná hodnocení. Charakterem je blízká části vstupní, spolu s ní tvoří pomyslný rámec kurzu. Hodnotící limity jsou nejčastějším tématem této části (z výzkumného hlediska jsou zahrnuty do kategorie "obsahu řízení"). Určeny byly jasně a bez emocí; konkrétní počet bodů, kterých studenti nakonec dosáhli, však nebyl veřejně znám - v tom je opět patrná role systému, který umožňuje hodnocení utajené, prováděné mimo zraky ostatních.

Nakonec je ještě vhodné poznamenat, že hledané kategorie vyjádřené kódovacím schématem měly formu jak negativní, tak pozitivní ${ }^{14}, v$ textech však výrazně převažovala jejich pozitivní forma. Vytyčováno tedy bylo to, do jakých oblastí učitelé smí zasahovat, naopak přiliš nebylo vyjednáváno, kam zasahovat nesmí. Hranice virtuálního a reálného světa tak působí spíše rozostřeně.

Autorita učitele se tedy $v$ různých mnou vymezených částech kurzu (části vstupní, části ohraničující výukovou lekci, části výstupní a části akční - pohyb v prostředí) odlišuje dle toho, zda zasahuje do oblastí obsahových, prostorových nebo časových. V počátku se tak pedagogové stávají těmi, kteří umožňují studentům vstup do prostoru. Činí tak především tím, že ukazují jeho hranice, jak prostor funguje a jaké jsou způsoby jeho ovládání. Před jednotlivými výukovými lekcemi stanovují časové plány, kterými se snaží strukturovat činnost studentů i průběžně. Se systémem se studenti zatím seznamují, jeho akční role je patrnější až v samotném oddílu jednání - část Pohyb v prostředí. Tam již prostor a čas učitelé strukturovat nemusí - děje se tak pomocí softwaru Moodle. Je zde prostor na diskusi mezi vyučujícími a studenty, kteří ve vzájemné interakci diskutují obsahové hranice, učitelé studentům nechávají v tomto poměrnou volnost, umožněnou skrytými mantinely prostředí.

Celkově jsme tedy získali obraz autority, která byla $v$ tomto konkrétním virtuálním kurzu utvářena specifickým způsobem. Ve vstupní části byla více utvářena učiteli, po ustanovení pravidel však byla částečně delegována na prostředí a tak docházelo ke zdánlivému rozvolnění autority. Moodle jako takový nebyl samostatným aktérem, byl jen pomocnou složkou, jejíž roli však nesmíme opomenout; podoba vztahu učitele a žáka tak byla determinovaná prostředím, ve kterém se interakce odehrávala.

${ }^{13} \mathrm{~V}$ anglickém originále dostupné na: COŽP. VCSE/Globalisation09/Forums/Discussion forum/Further discussion.In: MPG\&SD, Electronic course in Moodle. Wednesday, 21 October 2009, 11:55 AM (online). (cit. 08-04-2010) Dostupný $z$ internetu pro registrované účastníky: WWW: http://www.vcse.eu/moodle/course/view.php?id=7

${ }^{14}$ Pozitivita či negativita je vysvětlena $v$ koncepci Colemanova schématu - jde o princip, zda autorita ovlivňovala, kam smí (pozitivní kategorie) či kam nesmí (kategorie negativní) zasahovat. 
Vrátíme-li se k počátečnímu vymezení autority dle Colemana, nacházíme v jeho teorii ještě jeden aspekt, který můžeme vztáhnout k výsledkům mého výzkumu. Coleman dělí vztahy autority na jednoduché a komplexní. Ve vztahu jednoduchém je pouze nositel autority a autoritě podř́zený, ve vztahu komplexním je pak autorita vykonávaná jiným subjektem, než tím, na koho byla převedena. Implikuje tedy tři aktéry - osobu autoritě podřizenou, nositele autority a tzv. poručníka, reálného vykonavatele (Coleman 1994: 81 -82). Tohoto poručníka nacházím ve svém výzkumu v Moodlu - na něj je převedena část výkonu autority, která je primárně v rukou učitele. Neřídí však všechno jednání, je spíše prostředníkem, z větší části totiž učitelé sami stanovují koncepci řízení, která je zprostředkovaná skrze Moodle.

Charakter kurzu a podobu autority $v$ něm utvářené však nemůžeme připisovat pouze třísložkovému vztahu učitele, žáka a prostředí. Vysvětlení můžeme hledat i v celkové podobě tohoto konkrétního př́ipadu - MPG\&SD byl předmětem vyučovaným $v$ rámci vysoké školy a jednalo se o kurz volitelný, částečně tedy můžeme jeho charakter připisovat odlišnému př́stupu ke studiu, který mají vysokoškoláci, a jejich dobrovolné participaci. I přístup učitelů $v$ tomto bodě může být odlišný, protože na rozdíl od kurzů povinných musí neustále udržovat zájem participantů. Svoji roli může hrát i zaměření kurzu - otázky týkající se životního prostředí a globalizace zajímají určitý druh lidí, jejich chování tudíz mohlo být tímto faktem ovlivněno.

\section{Diskuse výsledků, závěry}

Výsledky, ke kterým jsem došla v rámci mého výzkumu, mne vedou k domněnce, že další zkoumání e-learningových metod i $v$ kurzech povinných by mohlo přinést nový zajímavý materiál, který by popisoval i jiné aspekty vztahu učitel - žák s ohledem na projevy autoritativního řízení. V mé případové studii jsem nezjistila žádné vážnější konfliktní situace, pokud by však došlo $v$ této oblasti $\mathrm{k}$ dalším výzkumům, kde by se konflikty vyskytovaly, daly by se zde zkoumat vyrovnávací postupy, skrze které by se aktéři pokoušeli dostat kurz do původních hranic. Zajímavé by bylo, zda by tato iniciativa probíhala přímo ze strany učitelů či zda by i $v$ tomto případě bylo použito technických funkcí, které nabízí virtuální vyučování.

Výsledek mé práce je pouze př́padovou studií jednoho konkrétního kurzu, nečiní si tedy ambice na zobecnění na podobné kurzy tohoto typu. Jde však, myslím, o zachycení určitých vývojových trendů v nové oblasti vyučovacích metod, které se mohou stát dominantní. Co se týče využití teoretické inspirace (Colemanův pohled na autoritu jako sociální směnu), byl učiněn poněkud smělý krok, jehož pomocí se však podařilo odhalit některé význačné rysy autoritativního vztahu $v$ prostředí, které s Colemanovým pohledem koresponduje $z$ hlediska určitého typu racionality.

Kvalitativní výzkum, kterému jsem se věnovala, může být chápán jako prvotní zmapování dané problematiky, které může být podkladem pro další šetření v této oblasti; zachycené charakteristiky mohou být základním materiálem pro vytvoření kvantitativního výzkumu. K hlubšímu porozumění by bylo vhodné na výzkum navázat ještě kvalitativními hloubkovými rozhovory. Získali bychom tak pohled ze strany samotných aktérů, a tedy zjištění toho, co dělají, bychom rozšiřili o poznání toho, jak subjektivně interpretují a vnímají autoritu $v$ rámci virtuálního výukového kurzu. V rámci výzkumu je zajímavý i pohled na vztah autority $v$ kontextu interakcí na virtuální úrovni. Př́nosné by mohly být další výzkumy podobné problematiky, které by se nemusely zabývat pouze autoritativními vztahy, mohly by zkoumat i jiné aspekty vztahů, kde chybí kontakt "face to face".

Co se týče inspirace $v$ zahraničních výzkumech, myslím, že tato práce potvrzuje význam prostředí pro vztah mezi učitelem a žákem (Tirri, Puolimatka, 2000) a naznačuje, jakým způsobem dochází $\mathrm{k}$ posunu $\mathrm{v}$ roli učitele $\mathrm{v}$ rámci virtuálního prostoru, tak jak ji popsali ve své práci Linser, Waniganayake a Wilkes (2004: 21). 


\section{Literatura}

- Babad, E. (2009) Teaching and non-verbal behavior. In L. J. Saha \& Dworkin, A. Gary (Eds.), International Handbook of Research on Teachers and Teaching (pp. 817-827). Boston, MA: Springer US. Retrieved from http://www.springerlink.com/index/10.1007/978-0-38773317-3 http://dx.doi.org/10.1007/978-0-387-73317-3

- Cartelli, A. (Ed.), (2006). Teaching in the knowledge society. New skills and instruments for teachers. Hershey. PA: Information Science Pub.

- Coleman, J. (1994). Foundations of social theory.. Cambridge: Belknap Press of Harvard University Press.

- Dlouhá, M. (2010). Autorita ve virtuálním vzdělávání. Praha: UK FSV Institut sociologických studií.

- Durkheim, É., (1922). Éducation et sociologie. . Retrieved from http://classiques.uqac.ca/classiques/Durkheim emile/education socio/education socio.html

- Saha, L. J., \& Dworkin, A. Gary, (2009) Teacher-Student Interaction. In L. J. Saha \& Dworkin, A. Gary (Eds.), International Handbook of Research on Teachers and Teaching (pp. 711-722). Boston, MA: Springer US. Retrieved from http://www.springerlink.com/index/10.1007/978-0-387-73317-3 http://dx.doi.org/10.1007/978-0-387-73317-3

- Encyclopedia of social theory (2006). NY: Routledge.

- Hendl, J. (2008). Kvalitativní výzkum: Základní teorie, metody a aplikace. Praha: Portál.

- Linser, R., Waniganayake, M., \& Wilkes, S. (2004) Where is the Teacher? E-learning Technology, Authority and Authorship in teaching and learning. In L. Cantoni \& C. McLOUGHLIN (Eds.), Proceedings of World Conference on Educational Multimedia, Hypermedia and Telecommunications (pp. 3636-3641). Chesapeake, Norfolk VA: AACE.

- Pace, J. L. (2003). Revisiting Classroom authority: Theory and ideology meet practice. Teachers College Record, 105(8), 1559-1585.

- Steutel, J., \& Spiecker, B. (2000). Authority in Educational Relationships. Journal of Moral Education, 29(3), 323-337. Retrieved from http://www.tandfonline.com/doi/abs/10.1080/03057240050137373 http://dx.doi.org/10.1080/03057240050137373

- Tirri, K., \& Puolimatka, T. (2000). Teacher Authority in Schools: a case study from Finland. Journal of Education for Teaching, 26(2), 157-165.

- Waller, W. (1961). The sociology of teaching. New York: John Wiley.

- Weber, M. (1997). Autorita, etika a společnost. Praha: Mladá Fronta. 
Časopis Envigogika vydává Centrum pro otázky životního prostředí UK. Vývoj časopisu je podpořen projektem OP VK Mezioborová sít udržitelného rozvoje.

Více najdete na internetových stránkách projektu mosur.czp.cuni.cz
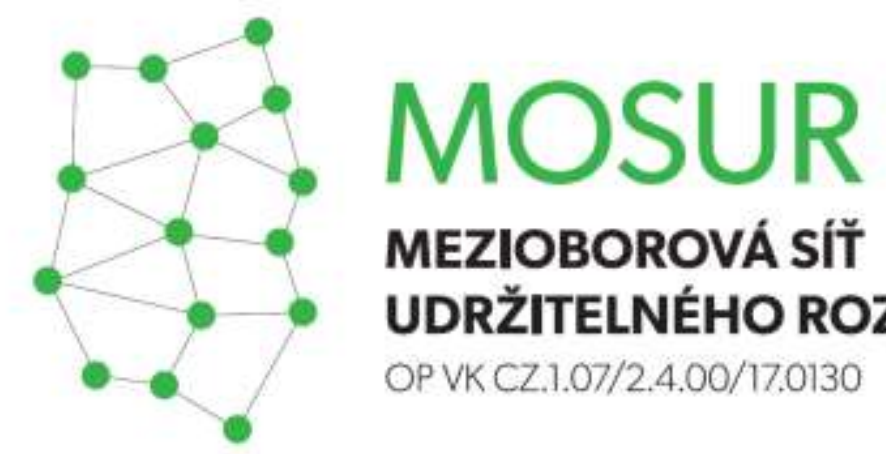

\section{MEZIOBOROVÁ SÍT} UDRŽITELNÉHO ROZVOJE

OP VK CZ.1.07/2.4.00/17.0130
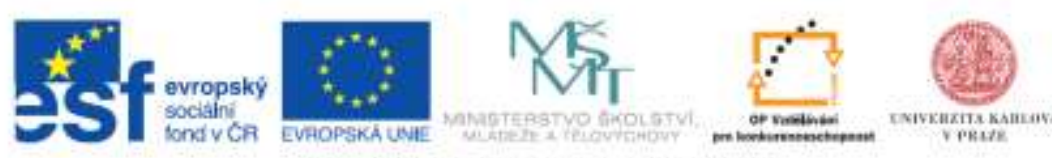

INVESTICE DO ROZVOJE VZDELAVANI 